\title{
The evolution of the project management
}

\author{
Catalin Drob, Ph.D, University "Vasile Alecsandri” of Bacau, Romania
}

\begin{abstract}
Project management has appeared and developed based on scientific management theory during the '50s-'60s of the last century.

After the 1990s of the last century, we can say that project management has truly become an independent discipline, which has a huge impact on the success or failure of companies which are engaged in major projects.
\end{abstract}

\section{Keywords}

Evolution, scientific management, project management.

Throughout time, humanity has put in place many grandiose projects. The history of these projects started to be written since 2,500 years BC, with construction of the impressive Egyptian pyramids. However, the first projects that have implemented specific aspects of project management were conducted, much later, in the twentieth century, in the United States, along with the revolution of management theories.

The roots of project management are related to the appearance and development of scientific management theory, whose promoters were: Frederick W. Taylor, Frank and Lillian Gilbreth, Henri Fayol and Henry Gantt.

In 1911, saw the light of printing a reference work which founded this theory: "The Principles of Scientific Management" written by Frederick W. Taylor. In this paper, F.W. Taylor postulated the scientific management principles, which in his opinion, are $^{1}$ :

- use of scientific methods of work;

- scientific selection of employees and improving the skills of employees;

- good cooperation with employees;

- scientific division of labor in skilled and unskilled labor and its proper allocation between managers and workers.

Frank and Lillian Gilbreth had an important contribution to developing scientific management, mainly in the field of industrial psychology. The best known work regarding with this area was written by Lillian Gilbreth and entitled "The Psychology of Management" published in 1912.

In 1916, appeared another book that had a huge impact on management theory: "Administration Industrielle et Generale" (Industrial and General Administration), whose author was the French engineer Henri Fayol, regarded as the founder of classical management theories of organization. In this paper, H. Fayol has noted that the basic principles of management should consider ${ }^{2}$ :

- division of labor, which involves breaking down complex works into simpler and more consistent work and their allocation of specialized workers;

1 Turcu, O.L., Mironescu, R., Drob, C., Simionescu Gh., Feraru, A., Stan, A. (2008), Management, Ed. Alma Mater, Bacău, p. 15;

${ }^{2}$ Nica, P. (1994), Managementul firmei, Ed. Condor, Chişinău, p. 32. 
- authority, which is viewed as the legitimate right to give orders;

- discipline, which implies the respect of the intern rules;

- unity of command, which means that each employee should receive orders from only one manager;

- unity of direction, which means that the entire organization to have the same vision and direction to pursue common objectives using a single plane;

- the subordination of individual interests to those of the organization;

- remuneration, which must be properly determined according to performance of the workers;

- centralization, which implies that power and authority are concentrated at the upper levels of the organization's management;

- hierarchy, which involves establishing an adequate number of hierarchical levels, allowing for efficient movement of information both from the top to its base organization and vice versa;

- order, which must be set up in the organization so that every employee and material object to have its place and to find there;

- equity and fairness set up in relations between managers and his staff;

- staff stability;

- encouraging initiative;

- development of team spirit.

In the United States, the father of project management is considered Henry Gantt, who developed a technique of planning and control, called the Gantt chart that is currently used in the project management.

Among major American projects, which considered the application of such principles of management, we can mention ${ }^{3}$ :

- construction of the giant dam on the Colorado River (1931-1936), named Hoover dam, in honor of the United States President, Herbert Hoover. This dam, which has 201 meters thick at the bottom and has 221 meters in height, is still one of the most impressive hydro dams;

- Manhattan Project (1942-1945), which led to the production of the atomic bomb and which have involved over 125,000 people etc.

Starting from the core of the general management theory and from the need to apply the principles, methods and management specific techniques in the projects field, during the '50s and 60 's, began to take shape a discipline in its own right, named Project Management. In the first part of this period, the application of project management in projects was limited mainly in use of the Gantt charts.

The Gantt chart is the simplest and the most popular graphic method used for planning and control activities. This chart is actually a graphical representation of activities to be undertaken within a project, on the time scale.

During '50-'60's of the last century, the development of large projects puts in the light the fact that the management methods and techniques used until that time were outdated and that the management theory and practice must be adapted to the specific of the projects.

The specialized literature shows that the application for the first time of new methods and techniques of project management was undertaken in 1958, for the Polaris project of the U.S. Navy's, which involved designing and making of nuclear ballistic missile named "Polaris" that can be attached on submarines. Thus, within this project was designed and used a new technique for evaluation and analysis of the programs known as PERT (Program Evaluation and Review Technique), which is commonly used in current projects.

This technique involves building a PERT chart type, which is a type of network graph

${ }^{3}$ Drob, C. (2010), Management de proiect, Ed. Alma Mater, Bacău, p. 9. 
that contains information about project activities, their duration, dependencies between them etc. PERT method is characterized by having regard to the risk and uncertainty, using probabilistic estimates for the duration of the activities. Pert method use three estimates to assess the duration of an activity: one optimistic, one pessimistic and one considered to be the most likely.

Around the same time, in a joint venture company founded by DuPont and Remington Rand companies, was introduced for the first time, a specific method of project planning named critical path method, known as CPM. Critical Path is defined as the minimum duration of the project for which events on the critical path have no time reserve.

In the late '60s of the last century, in 1969, in United States, was founded the first organization who proposed the promotion and development of the project management: Project Management Institute.

"70-'90 period of the twentieth century was characterized by the expansion of the hardware and software technology, starting with the launch on the market of the first micro-computers and PCs. In the first part of this period were developed first specifics software for project management, later these becoming cheaper and more available.

Thus, after creation of the Microsoft company in 1975 by Bill Gates and Paul Allen and starting with the development in computer technology were founded the first companies that proposed specific software for project management: Artemis (1977), Oracle (1977), Scythian Corporation (1979) etc.

In 1983, was launched the Harvard Project Manager, considered one of the first integrated software specialized for project management. This program was able to make planning of tasks, budget and resources. Subsequently, on the market dedicated to the project management programs appeared and other companies that proposed various solutions for solving specific problems of project management.

In 1998, in an article published in "Project Management Journal", was released a top of the most used software for project management. The Top 10 positions were occupied as follows ${ }^{4}$ :

1. Microsoft Project;

2. Primavera Project Planner;

3. Microsoft Excel;

4. Project Workbench;

5. Time Line;

6. Primavera SureTrak;

7. CA-SuperProject;

8. Project Scheduler;

9. Artemis Prestige;

10. FasTracs.

After 1995, starting with the widespread diffusion of the Internet, the software used for project management began offering the option to connect and work jointly in an intranet or Internet network.

Today, the software for project management, are found in great diversity, both in terms of functions they develop and price that are sold on the market.

In the late 90's of the last century, Project Management Institute has proposed a set of standards and practical guidance for this area, that are incorporated in a document known as PMBOK (Project Management Body of Knowledge), which defines the fundament of management project for several fields, such as engineering, construction, IT and so on.

\footnotetext{
${ }^{4}$ Drob, C., Macarie, F. (2007), Management de proiect, Ed. Alma Mater, Bacău, p. 57.
} 
Project Management Institute describes the life cycle of a project through group processes, considering that, in fact, projects consist in a set of processes ${ }^{5}$.

After the 1990s, we can say that project management has truly become an independent discipline, which has an impact that become more important in the success or failure of large companies.

Once with awareness of benefits that may result from implementation of project management has increased the number of companies that apply the projects management in theirs projects we have developed its fields of application.

According with Project Management Institute, in 2006, there were over 200,000 people who have obtained certification recognized by this organization, after passing a rigorous exam based on PMBOK standard. The certificate granted by the Project Management Institute offers professional credibility in the project management field for its holders.

If initially the project management has found application in the military and the construction field, at present, it has exceeded the boundaries of industrial, making his presence felt in the social or political area.

\section{Conclusion}

The appearance and development of the project management has occurred as a consequence of the need to adapt the theory and practice of management to the projects specific. In practice, the application of the tools and techniques of project management is facilitated by the use of specialized software for project management.

\section{References}

1. Drob, C. (2010), Management de proiect, Ed. Alma Mater, Bacău.

2. Drob, C., Macarie, F. (2007), Management de proiect, Ed. Alma Mater, Bacău.

3. Nica, P. (1994), Managementul firmei, Ed. Condor, Chişinău.

4. Project Management Institute. (2008), A guide to the Project Management Body of Knowledge, Ediţia a patra, U.S.A.

5. Turcu, O.L., Mironescu, R., Drob, C., Simionescu Gh., Feraru, A., Stan, A. (2008), Management, Ed. Alma Mater, Bacău.

5 Project Management Institute. (2008), A guide to the Project Management Body of Knowledge, Forth Edition, U.S.A., p. 37. 